\title{
Detection of anti - Rickettsia spp. antibodies in domestic chickens of extensive breeding in an endemic area for spotted fever in the state of Rio Grande do Sul, Brazil
}

\author{
Detecção de anticorpos anti - Rickettsia spp. em galinhas domésticas de criação extensiva em uma \\ área endêmica para febre maculosa no estado do Rio Grande do Sul, Brasil
}

\author{
Jonas Fernandes Maciel $^{{ }^{*}}$ Felipe da Silva Krawczak ${ }^{\mathrm{II}}$ Caroline Sobotyk de Oliveira ${ }^{\mathrm{I}}$ \\ Jonas Moraes-FilhoII Marcelo Bahia LabrunaII Sônia de Avila Botton ${ }^{I}$ \\ Fernanda Silveira Flores Vogel $^{\mathrm{I}}$ Luis Antonio Sangioni ${ }^{\mathrm{I}}$
}

ABSTRACT

The goal of this study was to investigate antiRickettsia spp. antibodies in sera of domestic chickens (Gallus gallus domesticus) of extensive breeding in Cerro Largo county, considered an endemic area for spotted fever in the State of Rio Grande do Sul, Brazil. Three hundred blood samples were collected and anti-Rickettsia spp. antibodies were evaluated by indirect immunofluorescence assay (IFA) in the sera obtained. The occurrence of anti-Rickettsia spp. antibodies detected in this study was $1.33 \%$ (4/300), with endpoint titers ranging from 64 to 256 for Rickettsia rickettsii, $\boldsymbol{R}$. parkeri and/or $\boldsymbol{R}$. bellii. The results suggest these domestic chickens do not participate as a reservoir and/or amplifying host in the epidemiology of spotted fever in that endemic area. The present study consists in the first serological survey in Gallus gallus domesticus to rickettsiae-spotted fever group in Brazil.

Key words: indirect immunofluorescence assay, antibody, rickettsiosis, domestic chicken.

RESUMO

Este estudo teve como objetivo pesquisar anticorpos anti-Rickettsia spp. em soros de galinhas domésticas (Gallus gallus domesticus) de criação extensiva, provenientes de área considerada endêmica para febre maculosa no estado do Rio Grande do Sul. Foram coletadas 300 amostras de sangue e os soros obtidos foram testados para anticorpos anti-Rickettsia spp. pela Reação de Imunofluorescência Indireta (RIFI). A ocorrência de anticorpos anti-Rickettsia spp. observada foi de 1,33\% (4/300), com títulos variando de 64 a 256 para Rickettsia rickettsii, Rickettsia parkeri e/ou Rickettsia bellii. Os resultados sugerem que essas galinhas domésticas não participam como reservatório e/ou hospedeiro amplificador na epidemiologia da febre maculosa na área endêmica. O presente estudo consiste na primeira pesquisa sorológica em Gallus gallus domesticus para rickettsia do grupo da febre maculosa no Brasil.
Palavras-chave: reação de imunofluorescência indireta, anticorpos, rickettsioses, galinhas domésticas.

\section{INTRODUCTION}

The genus Rickettsia belongs to the order Rickettsiales, it is composed of different obligate intracellular bacteria species which are important causative agent of human and animal infectious diseases. An important zoonotic infection characterized by acute rash illnesses spread by ticks around the world, globally called spotted fever, is caused by Rickettsia spp. (PAROLA et al., 2005). In Brazil, the main etiological agent of Brazilian Spotted Fever (BSF) is Rickettsia rickettsii, considered the most pathogenic species of the genus for humans and some animals. Furthermore, this bacterium is transmitted by Amblyomma cajennense and Amblyomma aureolatum ticks (PINTER \& LABRUNA 2006; SOARES et al., 2012). The occurrence of $\boldsymbol{R}$. rickettsii has been confirmed in the Southeastern Brazilian region, where it was isolated and/or detected by molecular methods in humans, animals and ticks (LABRUNA et al., 2011).

Other reports of tick-borne rickettsial pathogens in South America refer to Rickettsia parkeri, the etiologic agent of a spotted fever associated to skin rashes and swollen lymph nodes. This agent is transmitted by Amblyomma triste in

'Departamento de Medicina Veterinária Preventiva (DMVP), Universidade Federal de Santa Maria (UFSM), Av. Roraima, 1000, Prédio 44, Sala 5149, 97105-900, Camobi, Santa Maria, RS, Brasil. E-mail: jonasfernandesmaciel@gmail.com. *Autor para correspondência.

"Departamento de Medicina Veterinária Preventiva e Saúde Animal, Faculdade de Medicina Veterinária e Zootecnia, Universidade de São Paulo (USP), São Paulo, SP, Brasil. 
Brazil, Uruguay and Argentina (VENZAL et al., 2004; SILVEIRA et al., 2007; NAVA et al., 2008; CONTI-DÍAZ et al., 2009; ROMER et al., 2011). In Brazil, the occurrence of a new strain of Rickettsia, genetically similar to $\boldsymbol{R}$. parkeri, was diagnosed in humans in São Paulo and Bahia states (SPOLIDORIO et al., 2010; SILVA et al., 2011). This new strain is called "Atlantic" and it is transmitted by Amblyomma ovale, Amblyomma aureolatum and Rhipicephalus sanguineus (SABATINI et al., 2010; MEDEIROS et al., 2011). In other Brazilian regions, human cases of BSF were diagnosed mainly by indirect serological methods, which did not allow the identification of Rickettsia species. Moreover, cross-reactions are very often among almost all Rickettsia spp. In South of Brazil, in Santa Catarina state, there were reports of human cases of BSF confirmed only by serology; however, Rickettsia sp. strain "Atlantic" was detected in ticks in this location (MEDEIROS et al., 2011).

Some rickettsiae, such as Rickettsia bellii, Rickettsia amblyommii, Rickettsia rhipicephali, and Rickettsia monteiroi are considered nonpathogenic or unknown pathogenicity. They have been reported infecting Amblyomma spp., Haemaphysalis spp. and Ixodes spp. in Brazil (LABRUNA et al., 2011). Concerning to these microorganisms, only $\boldsymbol{R}$. bellii and $\boldsymbol{R}$. monteiroi are not genetically and serologically related to the spotted fever group species (PAROLA et al., 2005).

The birds are among the preferred hosts of the immature stages of many species of Amblyomma spp. ticks in Brazil (ARZUA et al., 2003; OGRZEWALSKA et al., 2010, 2011, 2012; LUZ et al., 2012). The ticks which are parasitizing these hosts also take advantage of their mobility to the geographical dispersion. Epidemiologically, this spread becomes more important if these ticks are vectors harboring infectious agents (MOVILA et al., 2012). Studies on the prevalence of Rickettsia spp. in ticks of parasitic life in birds have been performed in various locations around the world, including Brazil (LABRUNA et al., 2007; OGRZEWALSKA et al., 2010, 2011; LUZ et al., 2012). All of these studies were carried out in wild birds, especially in Passeriformes. Furthermore, there is a lack of serological studies of rickettsiosis in wild or domestic birds as well as the demonstration of their role as an amplifier or reservoir host in the epidemiology of the BSF (OGRZEWALSKA et al., 2012).

The aim of this study was to determine the occurrence of anti-Rickettsia spp. antibodies in domestic chicken (Gallus gallus domesticus) from extensive breeding farms and verify epidemiological significance as reservoir and/or amplifying hosts of the etiological agent of spotted fever in an area considered endemic for BSF in Rio Grande do Sul state (RS), Brazil.

\section{MATERIAL AND METHODS}

Endemic area

This study was performed from May to November 2011 and included 29 farms in the municipality of Cerro Largo, northwest of RS ( $28^{\circ}$ $08^{\prime} 49$ 'S, 54 44'17" W). Human cases of BSF were reported in rural areas of this town; however the etiological agent associated with the disease has not been isolated (SANGIONI et al., 2011). These farms of this study were small areas, employing family labor, breeding extensively various domestic animal species, including domestic chicken. All the farms were located adjacent to native forest areas.

\section{Sampling}

In this research it was collected a total of 300 blood samples from chickens (Gallus gallus domesticus). This sampling was established based on calculus of infinite population in according to THURSFIELD (2004). All of the poultry were breeding extensively and potentially exposed to tick parasitism, being observed the presence of Argasidae in the majority of these birds. To procedure of the blood samples collection, the birds were properly contained and carried out the ulnar venipuncture without anticlotting. Following, the blood samples were placed in $10 \mathrm{~mL}$-fresh tubes and kept refrigerated in cool boxes for shipping. The samples were sent to the Laboratory of Parasitic Diseases at Universidade Federal of Santa Maria (UFSM), RS, Brazil. In the lab, the blood sera were obtained and kept frozen at $-20^{\circ} \mathrm{C}$ until the serological tests were performed.

Indirect fluorescent antibody assay

The serum of each chicken was tested by indirect immunofluorescence (IFA) using crude antigens of different species of Rickettsia, as previously described (HORTA et al., 2004). Serum samples were initially tested at 1:64 dilution in PBS for $\boldsymbol{R}$. rickettsii (strain Taiaçu) and $\boldsymbol{R}$. parkeri (strain AT24); both species are known as pathogenic and transmitted by ticks in Brazil. If any serum sample was reactive at least one of these two antigens, following titrations were performed for both antigens and for the other species of Rickettsia occurring in Brazil, such as $\boldsymbol{R}$. amblyommii (strain Ac37), $\boldsymbol{R}$. rhipicephali (HJ5 strain), R. felis (Pedreira strain) 
and $\boldsymbol{R}$. bellii (strain Mogi) in order to verify the possible antigen involved in seropositive cases, as previously established (HORTA et al., 2004, 2010; PIRANDA et al., 2008). In all reactions, it was used positive and negative control sera. The negative control serum was originated from a SPF chicken. To obtain the positive control, the same chicken was inoculated intramuscularly with an inoculum consisting of approximately $5 \times 10^{5}$ VERO cells infected with $\boldsymbol{R}$. rickettsii, and clinically monitored, especially by rectal temperature, until the $21^{\text {st }}$ day after inoculation. Later, the chicken was properly submitted to euthanasia and the blood serum was collected. In all reactions, the secondary antibody used was anti-chicken IgY produced in rabbit and labeled with fluorescein isothiocyanate (Sigma Diagnostics, St. Louis, MO) in a dilution at 1:3,000.

\section{RESULTS AND DISCUSSION}

The SPF chicken inoculated with $\boldsymbol{R}$. rickettsii showed no clinical signs during the 21 days post-inoculation. Additionally, the serum collected before inoculation demonstrated no reaction to rickettsial antigens. The highest antibody titer detected in the positive control serum was 4,096 in both $\boldsymbol{R}$. rickettsii and $\boldsymbol{R}$. parkeri. The SPF chicken serum was used at 1:64 dilution as positive control in all reactions.

In the 300 chickens sera initially tested by IFI for both $\boldsymbol{R}$. rickettsii and $\boldsymbol{R}$. parkeri, only four birds $(1.33 \%)$ were reactive to $\boldsymbol{R}$. rickettsii and/or $\boldsymbol{R}$. parkeri. Later on, these four samples were titrated for different rickettsiae and the titers were 64 to 128 to $\boldsymbol{R}$. rickettsii and $\boldsymbol{R}$. parkeri. In addition, no sample reacted to $\boldsymbol{R}$. amblyommii, R. rhipicephali or $\boldsymbol{R}$. felis. However, only one sample showed titer of 256 to $\boldsymbol{R}$. bellii (Table 1).

Cerro Largo was chosen as the target area for this research due to a case of BSF in human reported in 2007. Subsequently, an epidemiological study demonstrated antibody reagents (titer $\geq 64$ ) to $\boldsymbol{R}$. rickettsii and $\boldsymbol{R}$. parkeri in equines $51.6 \%(16 / 31)$, dogs $22.3 \%$ (6/27) and healthy human $29.6 \%(8 / 27)$. Two dogs showed $\boldsymbol{R}$. parkeri antibody titers at least four times greater than the titers for other Rickettsiae tested, suggesting that $\boldsymbol{R}$. parkeri (or a similar genotype) was circulating in that region (SANGIONI et al., 2011).

In the current study, it was observed that the domestic chickens were breeding freely in the farms. For this reason, they were potentially exposed to parasitism by ticks, and consequently to rickettsial infection. Furthermore, the poultry in this traditional breeding system have ingested a diversified natural diet such as a number of invertebrates (arthropods and annelids), which were infected by different species of rickettsiae, including $\boldsymbol{R}$. bellii (KIKUCHI \& FUKATSU, 2005; WEINERT et al., 2009). However, in this research, only $1.33 \%$ of the chickens showed spotted fever group anti-Rickettsia spp. antibodies. The highest antibody titer was 128 and it is considered less than the previously anti-Rickettsia spp. antibodies found in horses, dogs and humans in that endemic region (SANGIONI et al., 2011). These findings suggest that chickens have no epidemiological significance as reservoirs and/or amplifying hosts of the etiological agent of BSF in Cerro Largo. Probably the birds can be refractory to infection, or they are not being parasitized by the tick vectors of Rocky Mountain spotted fever. Nevertheless, these hypotheses need to be verified in further studies. Although the SPF chicken experimentally inoculated with $\boldsymbol{R}$. rickettsii exhibited no clinical signs, it seroconverted and displayed elevated titer (4,096). LUNDGREN et al. (1966) inoculated $\boldsymbol{R}$. rickettsii in different species of birds, including domestic fowls. The authors not detected antibodies titers by complement fixation test in domestic fowls; however it was demonstrated rickettsemia in these birds.

Table 1 - Anti-rickettsial antibodies titration in four serum-positive domestic chickens to R. rickettsii and/or R. parkeri from Cerro Largo, RS, Brazil.

\begin{tabular}{lcccc}
\hline Species & Chicken A & Chicken B & Chicken C & Chicken D \\
\hline R. rickettsii & 128 & 64 & -- & 128 \\
R. parkeri & 64 & -- & 64 & 64 \\
R. felis & -- & -- & -- & -- \\
R. bellii & -- & 256 & -- & -- \\
R. amblyommi & -- & -- & -- & -- \\
R. rhipicephali & -- & -- & -- & - \\
\hline
\end{tabular}

--: Not reactive serum to antibody titer $\geq 64$. 
In this study, a single chicken showed titer up to 256 to $\boldsymbol{R}$. bellii, interestingly this species does not belong to the spotted fever group. Although $\boldsymbol{R}$. bellii has been reported infecting a wide variety of ticks in Brazil (LABRUNA et al., 2011), species genetically similar to $\boldsymbol{R}$. bellii have been isolated from a variety of free-living invertebrates in the soil (KIKUCHI \& FUKATSU, 2005; WEINERT et al., 2009). Thus, the occurrence of a chicken with anti-R. bellii antibody titer up to 256 , at least four times higher than those of group rickettsiae spotted fever (Table 1), suggests that chicken may have been infected by ticks from different sources, including ingestion of some invertebrate infected by a rickettsia similar to $\boldsymbol{R}$. bellii.

\section{CONCLUSION}

This study is the first serological survey of domestic chickens of extensive breeding to rickettsiae of the spotted fever group. The results suggest that these chickens have slight epidemiological significance as reservoir and/or amplifying hosts of the etiological agent of spotted fever in Cerro Largo. Further studies must be performed in order to verify the role of chickens in the life cycle of rickettsias.

\section{ACKNOWLEDGEMENTS}

The authors would like to thank to Secretaria Municipal de Saúde de Cerro Largo, especially Ranieri Tonim and Francine Schwertner for their relevant contributions to this study. Additionally, the authors are grateful to the Brazilian federal funding bureaus which assist scientific research, Conselho Nacional de Desenvolvimento Científico e Tecnológico (CNPq) and Coordenação de Aperfeiçoamento de Pessoal de Nível Superior (CAPES), for scholarship and financial support.

\section{ETHICS COMMITTEE AND BIOSAFETY}

Regarding to all animal experimentation procedures, this study was approved by the ethical committee on animal experimentation of UFSM (Protocol number: 009/2011).

\section{REFERENCES}

ARZUA, M. et al. Amblyomma aureolatum and Ixodes auritulus (Acari: Ixodidae) on birds in the southern Brazil, with notes on their ecology. Experimental and Applied Acarology, v.31, p.283-296, 2003. Available from: <http://www.springerlink.com/ content/w2836g571v707747/>. Accessed: jun. 04, 2012. doi: 10.1023/B:APPA.0000010381.24903.1c.

CONTI-DÍAZ, I.A. et al. Serological evidence of Rickettsia parkeri as etiological agent of rickettsiosis in Uruguay. Revista do Instituto de Medicina Tropical de São Paulo, v.51, p.337339, 2009. Available from: <http://www.scielo.br/scielo. php?script $=$ sci_arttext\&pid=S0036-46652009000600005\&lng
$=$ en $\&$ nrm=iso $>$. Accessed: jun. 08, 2012. doi: 10.1590/S003646652009000600006.

HORTA, M.C. et al. Prevalence of antibodies to spotted fever group rickettsiae in humans and domestic animals in a Brazilian spotted fever-endemic area in the state of São Paulo, Brazil: serologic evidence for infection by Rickettsia rickettsii and another spotted fever group Rickettsia. American Journal of Tropical Medicine and Hygiene, v.71, n.1, p.93-97, 2004. Available from: <http:// www.ajtmh.org/content/71/1/93>. Accessed: jul. 07, 2012.

HORTA, M.C. et al. Experimental infection of the opossum Didelphis aurita by Rickettsia felis, Rickettsia bellii, and Rickettsia parkeri and evaluation of the transmission of the infection to ticks Amblyomma cajennense and Amblyomma dubitatum. Vector-Borne and Zoonotic Diseases, v.10, p.959967, 2010. Available from: <http://online.liebertpub.com/doi/ abs/10.1089/vbz.2009.0149>. Accessed: may 24, 2012. doi: $10.1089 / \mathrm{vbz} .2009 .0149$.

KIKUCHI, Y.; FUKATSU, T. Rickettsia infection in natural leech populations. Microbial Ecology, v.49, n.2, p.265-271, 2005. Available from: <http://www.springerlink.com/content/ k173273736566848/>. Accessed: jul. 05, 2012. doi: 10.1007/ s00248-004-0140-5.

LABRUNA, M.B. et al. Ticks collected on birds in the state of São Paulo, Brazil. Experimental and Applied Acarology, v.43, p.147-160, 2007. Available from: <http://www.springerlink.com/ content/4006438u3t003756/>. Accessed: jun. 06, 2012. doi: 10.1007/s10493-007-9106-x.

LABRUNA, M.B. et al. Rickettsioses in Latin America, Caribbean, Spain and Portugal. Revista MVZ Córdoba, v.16, p.2435-2457, 2011. Available from: <http:/www.doaj.org/ doaj?func $=$ abstract\&id $=862990>$. Accessed: jul. 12, 2012.

LUNDGREN, D.L. et al. Infectious diseases in wild animals in Utah. VI. Experimental infection of birds with Rickettsia rickettsii. Journal of Bacteriology, v.91, n.3, p.963-966, 1966. Available from: <http://jb.asm.org/content/91/3/963.abstract>. Accessed: aug. 04, 2012.

LUZ, H.R. et al. Bird ticks in an area of the Cerrado of Minas Gerais State, southeast Brazil. Experimental and Applied Acarology, v.58, n.1, p.89-99, 2012. Available from: <http://link.springer. com/article/10.1007/s10493-012-9572-7?null>. Accessed: sep. 02, 2012. doi: 10.1007/s10493-012-9572-7.

MEDEIROS, A.P. et al. Spotted fever group Rickettsia infecting ticks (Acari: Ixodidae) in the state of Santa Catarina, Brazil. Memórias do Instituto Oswaldo Cruz, v.106, p.926-930, 2011. Available from: <http://www.scielo.br/scielo.php?pid=S007402762011000800005\&script=sci_arttext $>$. Accessed: jul. 21, 2012. doi: 10.1590/S0074-02762011000800005.

MOVILA, A. et al. Detection of tick-borne pathogens in ticks from migratory birds in the Baltic region of Russia. Medical and veterinary entomology. v.27, p.113-117,2012. Available from: $<$ http://onlinelibrary. wiley.com/doi/10.1111/j.1365-2915.2012.01037.x/abstract>. Accessed: sep. 10, 2012. doi: 10.1111/j.1365-72915.2012.01037.x.

NAVA, S. et al. Rickettsia parkeri in Argentina. Emerging Infectious Diseases, v.14, p.1894-1897, 2008. Available from: $<$ http://wwwnc.cdc.gov/eid/article/14/12/08-0860_article.htm>. Accessed: aug. 19, 2012. doi: 10.3201/eid1412.080860. 
OGRZEWALSKA, M. et al. Ticks (Acari: Ixodidae) infesting wild birds in the eastern Amazon, northern Brazil, with notes on rickettsial infection in ticks. Parasitology Research, v.4, p.809816, 2010. Available from: <http://www.springerlink.com/content/ w236h24577544752/>. Accessed: jun. 08, 2012. doi: 10.1007/ s00436-010-1733-1.

OGRZEWALSKA, M. et al. Ticks (Acari: Ixodidae) infesting wild birds in the Atlantic Forest in northeastern Brazil, with notes on rickettsial infection in ticks. Parasitology Research, v.8, p.665-670, 2011. Available from: <http://link.springer.com/ article/10.1007/s00436-010-2111-8>. Accessed: may 19, 2012. doi: 10.1007/s00436-010-2111-8.

OGRZEWALSKA, M. et al. Epidemiology of Brazilian spotted fever in the Atlantic Forest, state of São Paulo, Brazil. Parasitology, v.139, p.1283-1300, 2012. Available from: <http:// journals.cambridge.org/action/displayAbstract? fromPage $=$ on line\&aid=8688495>. Accessed: dec. 12, 2012. doi: 10.1017/ S0031182012000546.

PAROLA, P. et al. Tick- and flea-borne rickettsial emerging zoonoses Veterinary Research, v.36, p.469-492, 2005. Available from: <http:// www.vetres.org/index.php?option $=$ com article \&access $=$ standard \& Itemid $=129 \&$ url=/articles/vetres/ref/2005/03/v4057/v4057.html $>$. Accessed: may 26, 2012. doi: 10.1051/vetres:2005004.

PINTER, A.; LABRUNA, M.B. Isolation of Rickettsia rickettsii and Rickettsia bellii in Cell Culture from the Tick Amblyomma aureolatum in Brazil. Annals of the New York Academy of Sciences, v.1078, p.523-530, 2006. Available from: <http:// onlinelibrary.wiley.com/doi/10.1196/annals.1374.103/abstract>. Accessed: may 26, 2012. doi: 10.1196/annals.1374.103.

PIRANDA, E.M. et al. Experimental infection of dogs with a Brazilian strain of Rickettsia rickettsii: clinical and laboratory findings. Memórias do Instituto Oswaldo Cruz, v.103, p.696-701, 2008. Available from: $<$ http://www.scielo.br/scielo.php?script=sci arttext\&pid=S0074-02762008000700012> Accessed: may 22, 2012. doi: 10.1590/S0074-02762008000700012.

ROMER, Y. et al. Rickettsia parkeri rickettsiosis, Argentina. Emerging Infectious Diseases, v.17, p.1169-1173, 2011. Available from:<http://wwwnc.cdc.gov/eid/article/17/7/10-1857 article. htm.>. Accessed: jun. 02, 2012. doi: 10.3201/eid1707.101857.

SABATINI, G.S. et al. Survey of ticks (Acari: Ixodidae) and their rickettsia in an Atlantic rain forest reserve in the State of São
Paulo, Brazil. Journal of Medical Entomology, v.47, p.913-916, 2010. Available from: <http://www.bioone.org/doi/full/10.1603/ ME10073>. Accessed: jun. 12, 2012. doi: <http://dx.doi. org/10.1603/ME10073>.

SANGIONI, L.A. et al. Rickettsial infection in Cerro Largo, State of Rio Grande do Sul, Brazil. Arquivo Brasileiro de Medicina Veterinária e Zootecnia, v.63, p.511-514, 2011. Available from: $<$ http://www.scielo.br/scielo.php?pid=S010209352011000200035\&script $=$ sci_arttext $>$. Accessed: may 23, 2012. doi: 10.1590/S0102-09352011000200035.

SILVA, N. et al. Eschar-associated Spotted Fever Rickettsiosis, Bahia, Brazil. Emerging Infectious Diseases, v.17, p.275278, 2011. Available from: <http://wwwnc.cdc.gov/eid/ article/17/2/10-0859_article.htm>. Accessed: may 27, 2012. doi: 10.3201/eid1702.100859.

SILVEIRA, I. etal. Rickettsia parkeri in Brazil. Emerging Infectious Diseases, v.13, p.1111-1113, 2007. Available from: <http://www. ncbi.nlm.nih.gov/pmc/articles/PMC2878225/?tool=pubmed $>$. Accessed: jun. 06, 2012. doi: 10.3201/eid1307.061397.

SOARES, J.F. et al. Experimental infection of the tick Amblyomma cajennense, Cayenne tick, with Rickettsia rickettsii, the agent of Rocky Mountain spotted fever. Medical and Veterinary Entomology, v.26, n.2, p.139-151, 2012. Available from: <http://onlinelibrary.wiley. com/doi/10.1111/j.1365-2915.2011.00982.x/full>. Accessed: sep. 15, 2012. doi: 10.1111/j.1365-2915.2011.00982.x.

SPOLIDORIO, M.G. et al. Novel spotted fever group Rickettsiosis, Brazil. Emerging Infectious Diseases, v.16, p.521-523, 2010. Available from: <http://wwwnc.cdc.gov/eid/ article/16/3/09-1338_article.htm>. Accessed: may 23, 2012. doi: 10.3201/eid1603.091338.

THURSFIELD, M.V. Epidemiologia veterinária. 2.ed. São Paulo: Roca, 2004. 556p.

VENZAL, J.M. et al. Rickettsia parkeri in Amblyomma triste from Uruguay. Emerging Infectious Diseases, v.10, p.14931495, 2004. Available from: <http://wwwnc.cdc.gov/eid/ article/10/8/03-0999_article.htm>. Accessed: may 10, 2012.

WEINERT, L.A. et al. Evolution and diversity of Rickettsia bacteria. BMC Biology, v.7, p.6, 2009. Available from: $<$ http:// www.biomedcentral.com/1741-7007/7/6>. Accessed: may 17, 2012. doi: 10.1186/1741-7007-7-6. 